\title{
Motivating Factors of Farmers to Engage Vegetable-based Agribusiness in East Java and Bali, Indonesia
}

\author{
Joko Mariyono ${ }^{1)}$ \\ ${ }^{1}$ Program Studi Magister Manajemen, Universitas Pancasakti, Tegal \\ Corresponding Author: email: mrjoko28@gmail.com
}

Recieved: July 2018 | Revised: November 2018 | Accepted: February 2019

\begin{abstract}
Vegetable crops play an essential role in the Indonesian economy through their multiplier effect in farm household livelihoods. This paper analyses factors determining farmers to enter agribusiness ventures based on vegetables. Intensive vegetable farming, as a part of agricultural commercialization, is considered a technological package that is more profitable, and high input and labor-intensive compared to rice and other cereal crops. The study employed a qualitative approach to describe farmers' motivation. Data for this study were compiled from surveys conducted in 2014 by interviewing 357 farm households, which were located in four major vegetable producing regions of East Java and Bali, Indonesia. Qualitative surveys and descriptive statistics approaches were used to support quantitative regression models. Analysis of data was conducted during July-September 2018. Results show that farmers were more motivated to commercialize because of economic and agroecological reasons. An enabling agribusiness environment such as access to good produce markets, credit, as well as market information and support systems access is expected to be other driving factors boosting commercial vegetable farming and associated steady growth of vegetable production in Indonesia. Vegetable markets should be emphasized in the potential vegetable producing regions of Indonesia.
\end{abstract}

Keywords: vegetable farming, farmers' motivations, descriptive analysis

JEL classification: Q12; Q18

How to Cite: Mariyono, J. (2019). Motivating Factors of Farmers to Engage Vegetable-based Agribusiness in East Java and Bali, Indonesia. Jurnal Ekonomi Pembangunan: Kajian Masalah Ekonomi dan Pembangunan, 20(2). doi:https://doi.org/10.23917/jep.v20i2.7186

DOI: https://doi.org/10.23917/jep.v20i2.7186

\section{Introduction}

Agribusiness, which is based on vegetable production, is profit promising because vegetables are high-valued products. Compared to rice and other cereal crops, vegetables provide high profitability if the vegetables are managed with a timely manner. Vegetables are daily demanded in fresh form, and the demand for the product is relatively stable. Many studies over the world have shown the business advantage of vegetable farming when farmers intensively operate farming for commercial purpose (Mariyono et al., 2017).
Seeing that movement from subsistence to commercialized agriculture is the key point of agribusiness, the government should encourage smallholder farmers to participate in the marketoriented farming. However, the commercialization of smallholder agriculture is not an instantaneous process. There are various requirements to achieve it. Leavy \& Poulton (2007) identify drivers of agricultural commercialization, i.e., population growth, technical change, enhanced market access, crop intensification, and asset accumulation. More comprehensively, Poole, Chitundu, \& Msoni (2013) highlight that 
commercialization of agriculture requires a series of certain attitudes, which comprise reduced time spent in markets, better product and process quality control and assurance, a low threshold of risk aversion, a dedication to farming and new technologies, better access to rural financial markets, willingness to invest in land and soil fertility, continuous improvement, improvement practices enhanced skills in managing agribusiness relations, efficiency enhancement starting from production to final product and better price negotiation. Also, group movement with the characteristic operational and management challenges is necessary for dropping transaction and transformation costs, and involves noteworthy individual and organizational education.

With respect to risk, farming is a risky business, and then the low threshold of risk aversion is one of the critical factors for successful agribusiness (Ikerd, 2011). One alternative to slash economic and ecological risks, as well as to increase farm profitability is agricultural diversification. Agricultural diversification with high-valued crops is also one of the several pathways to agricultural development (Kumar, 2009). Availability of advanced farming techniques becomes essential to support the commercialization. Improvement in land use intensification is only possible with nutrient replenishment to the soil to sustain its productivity. In subsistent societies, soil nutrient supply is replenished by farmyard manures. As output growth is intensive, commercially oriented agricultural production systems is not possible in the absence of chemical fertilizer application (Pingali \& Rosegrant, 1995). Unavailability of advanced agricultural technologies such as disease-free planting materials and diseasetolerant varieties has impeded the adoption of otherwise sound commercialization technologies is an example of the case in African cassava-based agribusiness (Mulu-Mutuku, Odero-Wanga, AliOlubandwa, Maling'a, \& Nyakeyo, 2013).
Diversification with high-value crops (and commercialization) of agriculture are driven by technological change (Pingali \& Rosegrant, 1995), then the adoption of agricultural technology becomes an important factor. Successful adoption of technology 'can be a powerful force in reducing poverty' (de Janvry \& Sadoulet, 2002: 1), and new technology seems to provide an opportunity to increase production and income substantially (Feder \& Savastano, 2017; Selvaraj, 2009).

Throughout history, changes in agricultural technology have always been an important component in the progress of human societies, and more so recently in the development of modern agriculture with a range of technologies (Huang, Hu, van Meijl, \& van Tongeren, 2004). A key innovation necessary to improve the productivity of diversified farming systems is the mass dissemination and adoption of agricultural technologies that are less costly and helps farmers manage and optimize input allocation in multiple crop systems. These technologies are costly, however, and the development of innovative lowcost, practical strategies that reduce the costs of production in diversified farming systems in the developing world will be necessary if they are widely disseminated (Bowman \& Zilberman, 2013).

Since the important agribusiness of intensive vegetable farming as a part of agricultural commercialization in Indonesia, this study evaluates the motivating factors related to commercialization. This also answers the question "why are some vegetable farmers more willing to commercialize their farming operations while others are still at the subsistence and semisubsistence levels.

\section{Review of Literature}

In recent years, vegetables continue to attract the international spotlight as a critical most-preferred option to addressing micronutrient malnutrition in both the developed and developing world through its direct impacts 
Jurnal Ekonomi Pembangunan: Kajian Masalah Ekonomi dan Pembangunan, 20 (2), 2019, 163-175

in improving dietary diversity and ensuring balanced diets among target populations. Presently, the importance of vegetables is prominent in enhancing food and nutritional security for the attainment of several of the Millennium Development Goals (Keatinge, Yang, Hughes, Easdown, \& Holmer, 2011). Production of vegetables also plays an important role in global agribusiness, due to it leading to increased farm productivity and higher farm gate values in comparison with cereal and other staple crops (Johnson, Weinberger, \& Wu, 2008; Weinberger \& Lumpkin, 2007).

Vegetables contain micro-nutrients, vitamins and phytochemicals that are needed for ensuring balanced diets while providing raw materials for pharmaceutical industries. Due mostly to the profitability of commercial vegetable production in comparison to rice and other cereal crops, the potential exists for much higher impacts through household income diversification, if more land can be devoted to intensified vegetable production by increasing per unit factor input application. In Indonesia, high-value vegetables such as chili, shallot, and tomato are an important part of daily dietary needs and livelihoods and play an important role in the overall economy of the country. Importantly, the household supply of the major staple, rice is only considered sufficient when it is complemented with supplies of other critical food condiments such as vegetables.

For chili specifically, a large part of national production is for meant for domestic daily consumption, and it has become a special commodity because of its capability to trigger high inflation rates. In 2010 for example, chili contributed $0.32 \%$ to total national inflation of $6.96 \%$ in Indonesia when chili prices soared to record highs, provoking outrage in a nation that eats the tongue burning spice for breakfast, lunch and dinner (BPS, 2011). At about $\$ 11 / \mathrm{kg}$, almost ten times the usual price and more expensive than beef and chicken meat, it has truly become an essential commodity on dining tables and in kitchens throughout Indonesia (O'Loughlin,
2011). In 2013, for example, the Indonesian Finance Minister reported that the country's inflation was higher than the target set in the state budget on food price hikes. Consequently, gasoline is no longer the major contributor to inflation in Indonesia as chilies have become a major variable in the equation. This particular spice, considered as a staple by most people, has increasingly become a luxury item.

To control the inflation rates, the government recommends creativity in the cultivation of vegetables as essential ingredients in Indonesian cuisine. In particular, households have been urged to grow their own chilies, in an attempt to deal with very high chili prices. Chili was still one of the sources of inflation in the foodstuff's component in January 2013. The price increased due mainly to lower domestic supply (Juniman, 2013). The government's assistance to farmers dealing with unpredictable agroclimatic variables is crucial in addition to enabling temporary trade policy such as using imports to meet seasonal internal supply deficits (Wicaksena \& Permani, 2011).

High-value vegetables are important cash crops, which provide a significant contribution to the local and national economy through its multiplier effects in income and employment generation, household nutrition and as raw material for industry. A transition from rice farming to commercial vegetable production is able to make the rural economy more vibrant through labor and other factor input-intensive farming. In some African countries, marketing vegetables increases household income (for example, Chagomoka, Afari-Sefa, \& Pitoro, 2014). In Indonesia, farmer incomes double and the agricultural inputs and products in the market increase substantially when farmers move from rice farming to intensive chili farming. The intensification triggers local markets, particularly through enhanced value chains of agricultural inputs and products. Due to vegetables being higher value cash crops and needing more inputs (particularly labor as well as material inputs) 
than cereal and other staple crops (Ali, 2016), multiplier effects of vegetable cultivation, such as employment creation, agribusiness development and local transportation accrue to the wider sectors of the rural community. At the national level, vegetable cultivation provides income, employment, and nutritional benefits to millions of smallholder farmers, rural laborers, and consumers.

Considering that intensive vegetable farming is important and plays an important role in supporting sustainable development goals and agrarian economy, enforcement of farmer to adopt vegetable farming is a must. However, there is still limited studies investigating the main determinants of farmers' decision to grow vegetables as the main components of agribusiness in rural areas. Several studies have analyzed such factors, but the results are still inconsistent and contradicting one another (among others: Nandi, Gowdru, \& Bokelmann, 2017; resulting in high transaction costs (TCs(Odiaka, Osupala, \& Odiaka, 2013; Sriwichailamphan \& Sucharidtham, 2014). Similar studies on other factors affecting farmers' decision related to intensive farming and technology adoption also measure the determinants at the same weightiness (Adanacioglu, 2017; Dong, Campbell, \& Rabinowitz, 2019; Durán \& Wives, 2018). This is because the importance of every determinant is scaled at the same degree, which mostly employed regression models to find significant determinants. Using regression models, the higher magnitude of estimated coefficients do not immediately mean the more important of the coefficients. Note that the magnitudes of the estimated coefficients are dependent on the measurement scale. Otherwise, the coefficients are converted in standardized value that compares the importance of the weighted impact of every independent variable on the outcome variable (Freedman, 2009). Based on the previous studies reviewed above, there is a hypothesis that factors motivating farmers to engage vegetablebased agribusiness to have different importance. This study will fill the gap by weighting factor determinants of farmers' engagement in the intensive vegetable farming system.

\section{Research Method}

\subsection{Model analysis}

Data analysis in this study employed a weighted average. This indicator provides a measurement that approaches to the real condition. The measurement represents the importance based on the number of stakeholders who have an interest in a particular aspect. An aspect will be considered very important if every stakeholder mentions that such aspect has a significance. The analysis was performed during July-September 2018, using data of the previous survey. The results were compared and contrasted with other findings of both the past and current studies. This approach is to show that this analysis is different from the others, in terms of methods and results of the analysis.

The procedure of analysis is as follow. In particularly relate to this analysis, every sampled farmer during the survey was asked to mention as many as possible motivations of why the farmer grew vegetables as commodities sold in the market. Then, the farmer was asked to provide a score of every motivation. The score was given a score of 10 if the motivation was the most important, and score of one if the motivation was least important. Factors not mentioned by farmers were automatically given a score of zero. The weighted average score (WAS) was calculated using a formula:

$$
W A S_{\text {Motivation }}=\frac{\sum n \times S}{N}
$$

where $n$ is the number of respondents that put the score, $S$ is the score, and $N$ is the total sample. For example, there are ten farmers mention and provide score respectively A and 3, B and 4, C and 2 , and so forth. Eight other farmers mention and provide score respectively $\mathrm{A}$ and $4, \mathrm{~B}$ and $2, \mathrm{C}$ and 3 , and so forth. If the farmer did not mention anything, the score was considered zero. From the survey, data were tabulated, and analysis was conducted using a weighted score, which can be calculated using the following table. 
Table 1. Tabulation of the weighted average score

\begin{tabular}{ccccccccc}
\hline Motivation & $\begin{array}{c}\text { Score } \\
\text { (S) }\end{array}$ & $\begin{array}{c}\text { Number } \\
\text { (n) }\end{array}$ & & $\begin{array}{c}\text { Score } \\
\text { (S) }\end{array}$ & $\begin{array}{c}\text { Number } \\
\text { (n) }\end{array}$ & $\sum \mathbf{n}$ & $\sum_{\times \mathbf{S}} \mathbf{n}$ & WAS \\
\hline A & 3 & 10 & $\ldots$ & 4 & 8 & 18 & 62 & 3.4 \\
B & 4 & 10 & $\ldots$ & 2 & 8 & 18 & 56 & 3.1 \\
C & 2 & 10 & $\ldots$ & 3 & 8 & 18 & 44 & 2.4 \\
$\vdots$ & & & $\ldots$ & & & & & \\
H & & & & & & & & \\
\hline
\end{tabular}

Thus, the higher the weighted average score, the more important the motivation perceived by farmers. The highest score will be five if all sampled farmers provide score five for a certain motivation. The lowest score will be zero if no farmer mentions a certain motivation.

\subsection{Study sites and samples of the study}

This study collected cross-section data from a field survey of 357 farm households conducted in 2014, in four districts: and Bangli and Tabanan of Bali; Blitar and Kediri of East Java, Indonesia. The total population of farmers growing vegetables was about 9500, which is based on the latest agricultural census (BPS, 2015). The regions were selected as the base of study because many producers of vegetable crops in these areas remained subsistence and trapped in a poverty cycle from season to season, which obstructs asset accumulation, investment and transition to commercial farming. Thus, the sample was about $4 \%$, which was purposively selected from rural areas where mostly subsistence household farmers stayed. The sites have distinct characteristics of the farming system and marketing channel that might shape vegetable-based agribusiness. Household-level data were collected using individual interviews using a structured questionnaire.

\section{Results and Discussion}

\subsection{Household characteristics}

Because information on household characteristics determines the effectiveness of project intervention, it is important to describe in agricultural development. The wrong target will have the potential for failure because the community will not be willing to accept the project. Figure 1 shows the main occupations of household heads in the study sites. Overall, more than $80 \%$ of household heads worked as a farmer as the main profession, and the remaining work was still related to agriculture. Head of household who did not provide information on the job means that they have jobs that include driver, raising livestock, and carpenter.

Figure2showsfarm-householdcharacteristics in the study sites. On overall average, farmers were still in the productive ages. Young mature farmers enable them to be more productive and responsive to agricultural innovation than older ones. The education level of household head was relatively low. On average, they spent time on schooling for about eight years, or equivalent to junior high school. This educational level is a big challenge for agricultural development because many studies show that formal education determines the success of agricultural innovation at farm level in Indonesia. To complement this condition, the project needs to provide additional non-formal education through relevant, adequate training (Luther, Mariyono, Purnagunawan, Satriatna, \& Siyaranamual, 2018)Indonesia. The FFS have equipped over 3,000 vegetable farmers with integrated crop management knowledge applicable to chilies and tomatoes. The FFS are expected to enhance farmers? capacity such that they can increase production. This study employs a difference?in?differences (DiD. Farmers were experienced in agricultural practices. On average they have been a farmer for about 17 years. Experience is one of the 
Jurnal Ekonomi Pembangunan: Kajian Masalah Ekonomi dan Pembangunan, 20 (2), 2019, 163-175

important factors determining the performance of agriculture. With such experience, it is not difficult for farmers to improve the performance of the farm. This is an important indicator of human capital. Farmers in studied areas mostly sort into smallholder farm, because they only held less than a hectare effective for farming. With such size, the traditional crop would be unable to provide sufficient income for normal livelihoods. Farmers with small landholding need to optimize the land with the commercialized crop to get a better income. Based on the comparison by sites, farmers in East Java relatively were older than those in Bali, but the differences were not too much. The education level of farmers in all regions was almost identical, except those from Kediri who completed junior high school. Farmers in Blitar were the least experienced among those from other regions, but the gap was not too big. Ten-year experience in agricultural practices was expected to be more than enough to pull alongside their corresponding items.

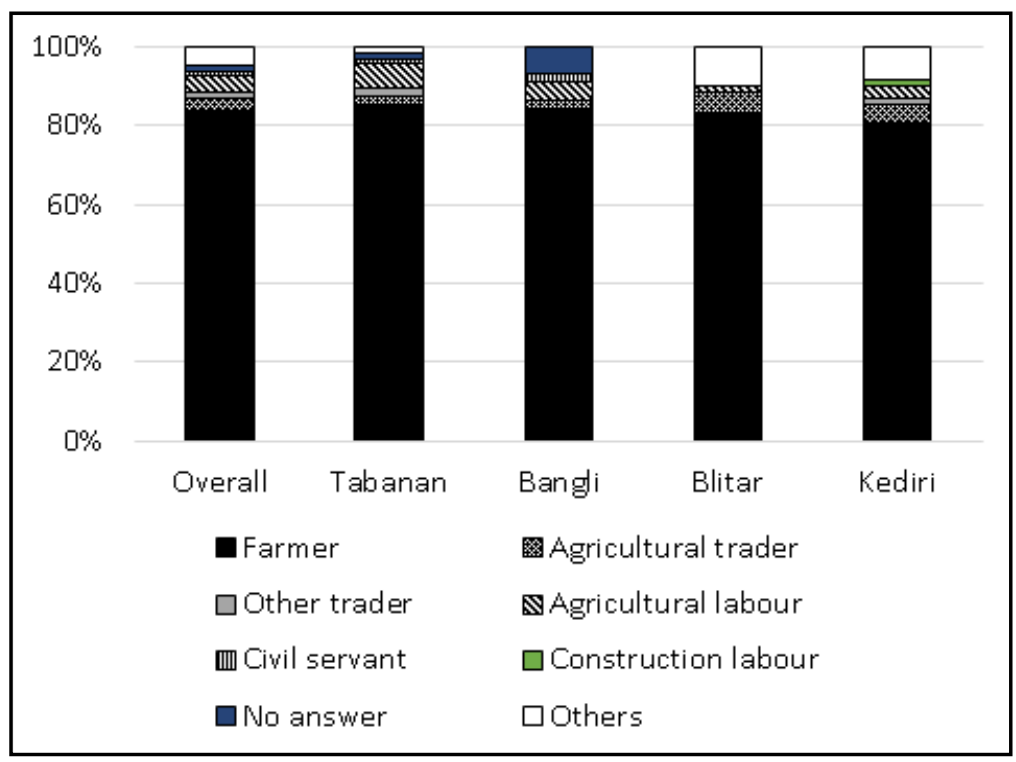

Figure 1. Main occupations of household heads

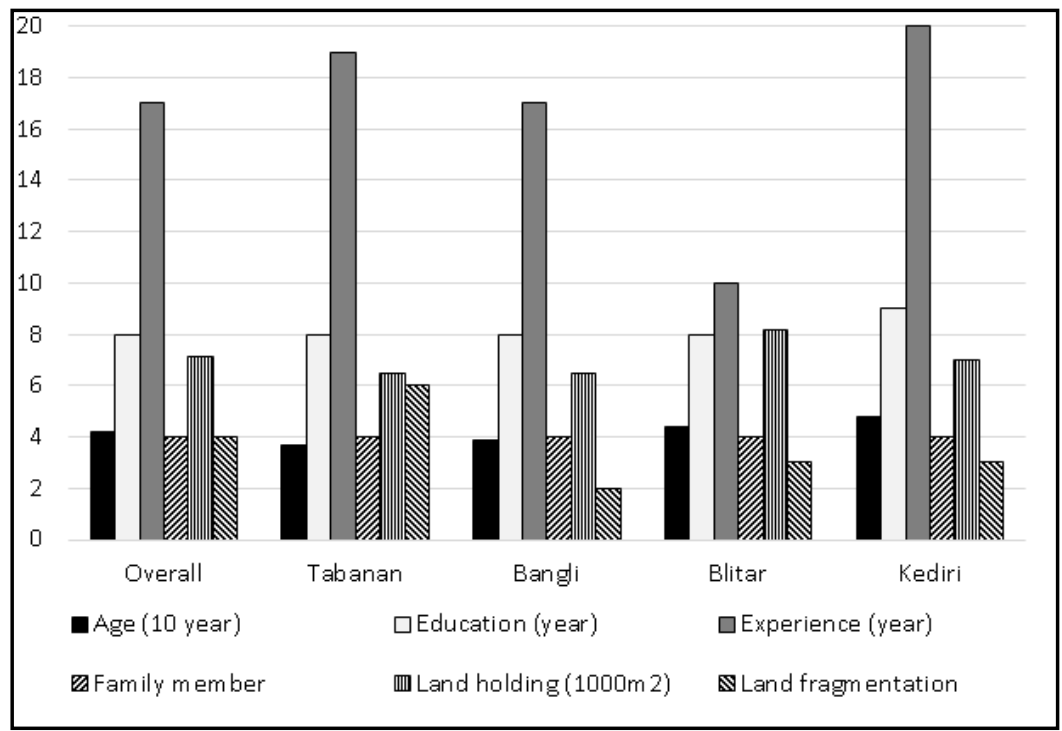

Figure 2. Farm-household characteristics 
Jurnal Ekonomi Pembangunan: Kajian Masalah Ekonomi dan Pembangunan, 20 (2), 2019, 163-175

\subsection{Motivations of intensive vegetable farming}

Figure 3 shows the overall motivating factors that encourage farmers to engage in vegetablebased agribusiness. Remarkably, farmers were more likely to engage in commercial vegetable farming due to their economic motive, which consisted of income generation, experience, and cropping pattern. This could be the case since experience could have different impacts. As farmers were usually risk averter, a negative impact of experience could be the case for higher risk aversion among older farmers (Feder \& Savastano, 2017). Agro-ecological factors dominated the motivation of farmers to engage vegetable-based agribusiness. Farmers had an awareness of the fact that vegetable farming has specific soil, water, and light requirements to achieve full production potential. A previous study shows a set of similar determinants in Indonesian vegetable farming (Noorhadi \& Sudadi, 2003). Fast-harvesting or fast-growing vegetable is also an important factor. Currently, seed technology that met market preference were available in the local market. Farmers could select as their preference. This is an indication that farmers grow vegetable because of the cash motive. Similarly, in sub-Saharan Africa, home consumption for ensuring food and nutrition security and generating extra income were reasons value chain actors mentioned for cultivating and commercializing vegetables (Chagomoka et al., 2014).

It is interesting to note that farmers entered vegetable-based agribusiness was not because of the extension from government's encouragement and program supports, particularly for a program called the Sustainable Food Reserve might not relevant to the rural situation. This is reasonable because in rural areas there is still plenty of land for horticultural crop cultivation. Unlike for urban, the program but would have a significant contribution to urban society. The program was launched in 2011 by the sixth President of Indonesia, who realized that high increases in vegetable prices, particularly chili, triggered significant inflation (Purwantini, Saptana, \& Suharyono, 2012). The program was promoting high valued commodities including high-valued vegetables to meet home consumption and to increase the income of households.

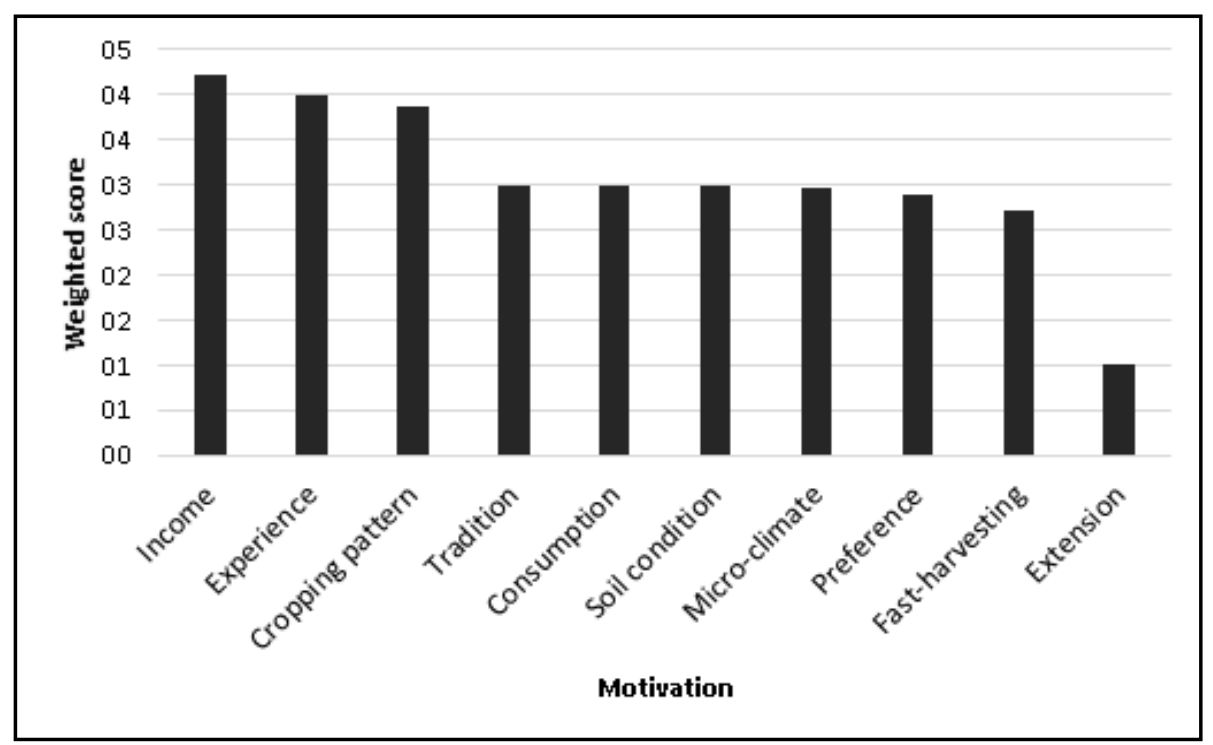

Figure 3. Overall motivation of farmers to engage agribusiness 
By site, Figure 4 shows the motivating factors that affected farmers to enter agribusiness on vegetable products. In Tabanan, the most motivating factors were home consumption, cropping patterns, and income generation. The extension was the least motivating factor. In Bangli, the most motivating factors were experience, cropping pattern and tradition; and unexpectedly, income generation was the least motivating factor. In Bangli, farmer society was still in firm cultural belief. They still held a belief that following the local culture and ism would generate good destiny. Thus, income was not necessarily the motive as long as they obey the culture, including agriculture. As the culture was still strong, the extension program was perceived as an important factor.

In Kediri and Blitar, the farmers' motivations to participate in vegetable-based agribusiness was almost similar. Economic and agro-ecological motives dominated farmers to conduct intensive vegetable farming as the base of agribusiness. The extension program was perceived as the least motivating factor. Note that in Kediri, Blitar, and Tabanan, the local cultures were not as strong as that in Bangli. The societies in three regions seemed to be more modern than in Bangli.

Based on the different motivations, let discuss the relationship between such condition and current situation. To increase the growth of vegetable production in Indonesia, it is understandable that a favorable business atmosphere should be formulated and adjusted according to local society. Note that commercial vegetable producers tend to be family-owned businesses rather than corporate businesses which require higher levels of returns on capital and management. Dey (2001) identifies the requirements for entering the commercial vegetable sector. The requirements consist of a site that offers access to markets, labor, good water quality, utilities and opportunity for future expansion; a high level of production management and the ability to apply intensive management skills to the crops; the ability to assess market potential; financial resources to invest in the development and operation of the business; the ability to juggle several activities at once; the ability to manage labor and to keep control of the financial affairs of the business as well as the production operations.

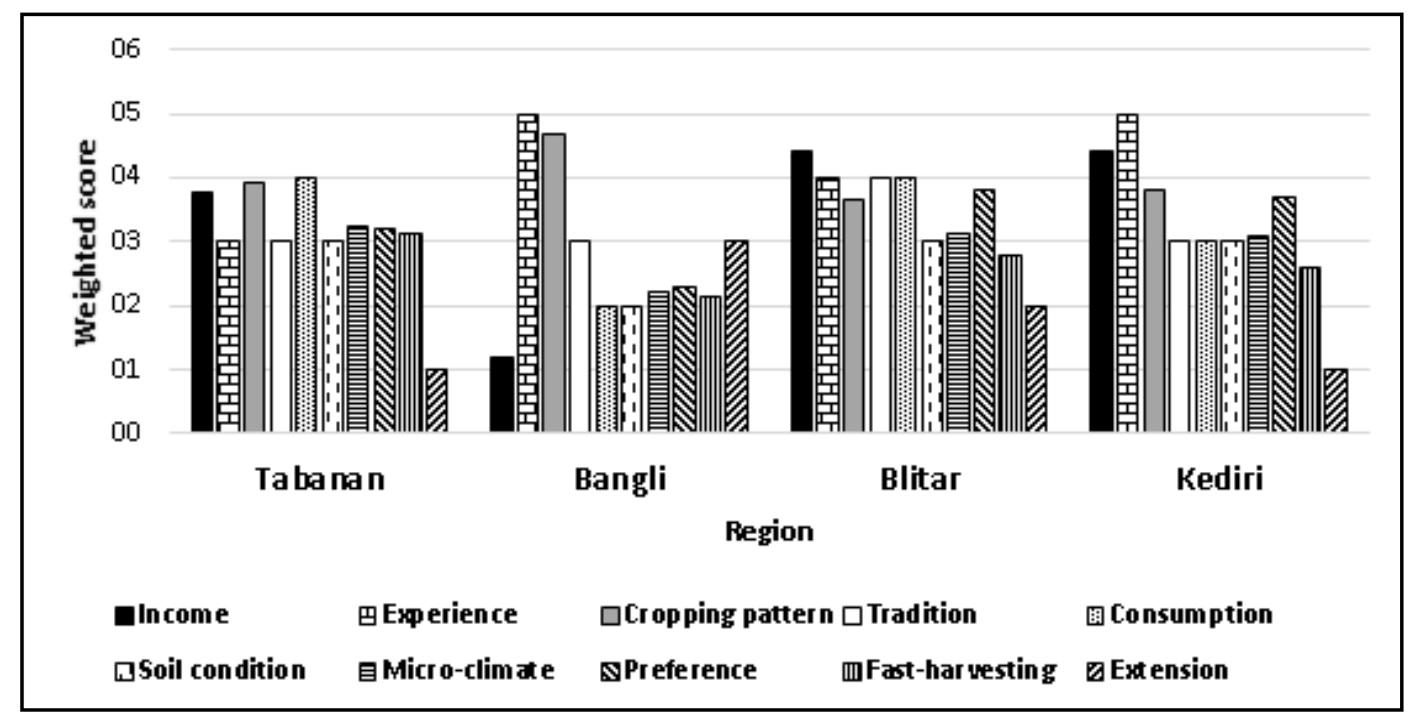

Figure 4. Motivation of farmers to engage agribusiness, by region 
In line with Woolverton, Okello, Binci, \& Neven (2014), the most plausible supposition from this analysis is that many smallholders interested in commercial production still lacked basic planning and marketing skills. Education and specific training can be provided in many ways, but given the heterogeneity of smallholder farmers, a local approach with a national perspective is best. These will enhance knowledge, skills, and the ability to respond to changes in the market are foundations for establishment and adoption of strategic management to run a commercial farm. There is an agreement that access to factor inputs and agronomic knowledge are also critical, but skills of small farmers should move from a production-oriented to a commercial motivation.

Access to fair market-price information offers the infrastructure for planning strategies. As price expectations are fundamental to commercial strategies, market-price information can be as simple as possible around the country. Ideally, information regarding quality premiums must also be available. Access to market-price information may take many procedures and may be as easy as facilitated regular farmers' meetings at the local level for information exchange.

Like many other small businesses, smallholder producers face difficulty to transition and grow without access to financial resources. Smallholder farmers also usually lack access to human resources who can explain loan terms and provide the micro-management often needed with higher risk borrowers. If financing is not well-managed and linked to a marketing strategy or collateral, loans can be quickly converted to grant schemes. Non-collateralized credit for agricultural production is frequently misused to other expenditures, often resulting in nonperforming loans. This loan default scenario is said to be one of the contributory factors in the sustained poverty trap of smallholder farmers in rural areas, ensuring that smallholder producers are not capable of accessing the resources required for investments in services and factor inputs.
The government and private sectors have equipped farmers with easy access to credit, in collaboration with rural cooperatives (Mariyono et al., 2019). In nearly every month of the primary planting seasons, mobile banks open to provide banking services in rural areas. If possible, it will help farmers access to credit from informal credit sources. These sources play an important role in providing credit (Turvey, 2017), particularly for those who have the reluctance to access credit from formal sources, such as a bank. Markets and supporting infrastructure have been established close to existing vegetable production regions to make it easy for farmers to sell their produce. In collaboration with international agricultural research centers, national research and development institutions have been discovering and disseminating vegetable-related technology over the past decade. All these factors have simultaneously led to the expansion of commercial vegetable production in East Java and Bali in particular, and Indonesia in general; and eventually farmers have gained higher income.

The role of the private sector seems important in this commercialization of vegetables. Longterm collaboration with the private sector can be developed for providing practical education as part of agribusiness services. But, without support, it is problematic for agribusiness service providers to work with farmers if they have to provide both the services themselves and the fundamental agribusiness education needed to make the services correctly beneficial to the farmers. Access to market-price information may also be assisted by the private sector, but the information must be impartial, truthful and accessible. The expectation in the market information system, whether public or private, can grow over time. Although using a mobile-phone to check market prices seems to have a positive relationship with a positive impact, it should be acknowledged that owning a mobile-phone is not a proxy for the actual uptake of market information. More efforts need to be done to alert farmers to the possibilities regarding how to use these tools and information. 
Eventually, income is necessary if smallholder farmers are to be able to treat vegetable production as a reliable source of income. That said, the development of a commercial orientation is a process, through which it is difficult for smallholders to start creating profits if their investment decisions are not explicitly linked to markets and marketing decisions. As the focus of policies and programs continues to step up towards helping smallholder farmers engage commercial rather than production strategies, this study provides a useful starting point for the design of right strategies and highlights the need for a parallel understanding of farmers' decisionmaking.

\section{Conclusion}

Intensive vegetable farming provides more income and employment than other crops, and the whole rural community benefits thereof. However, farming has largely been done by a small fraction of farmers. There is enough scope to increase the number of smallholder farmers playing in commercial vegetable farming. There are some major motivating factors affecting farmers to engage in intensive vegetable farming in East Java and Bali. Farmers were keen to run intensive vegetable farming because of economic and agro-climatic motives. These findings explain the substantial growth of vegetable production in Indonesia. The government has established vegetable markets or agribusiness terminals relatively close to vegetable production pockets, along with improvement in transportation modes and infrastructures in rural areas. Recently, information technology has been accessible to everyone, including farmer at affordable costs.

The practical implication for this study is when the government, along with private sectors, would like to increase the income of households in rural areas; intensive chili farming is one the best alternatives. However, as vegetable farming is drudgery-augmenting and complicated, the farmers who firstly cultivate vegetables need intensive supervision from experienced farmers. Training or internship in successful farmers will help those who newly grow vegetables. The scientific implication is to scrutinize more factors to complement this finding, particularly for other high-value horticultural crops that have the potential to improve the income of rural households.

The novelty of this study is the weighted motivating factors that encourage farmers to engage in profitable agribusiness through the intensive vegetable farming system. In many previous studies, factors affecting farmers to grow vegetable and other high-valued crops as the main component of agribusiness were considered the same importance. When the elements have different weighted importance, the policy could be misleading. Using the weighted average leads to an appropriate and correct policy formulation.

\section{Acknowledgement}

The author acknowledges the farmers and enumerators who provided and recorded information related to vegetable production in East Java and Bali; Dr. Victor Afari-Sefa, Dr Kuntoro B. Andri, Dr. Rofiq S. Basuki and Prof Dr. I Made S. Utama who assisted design questionnaire and coordinated field survey. The author also thanks the reviewers who provided valuable feedback and comments. This study is a part of the "Vegetables for Indonesia" project, funded by United States Agency for International Development (USAID)-Indonesia, led by Dr. Greg Luther, in collaboration with The Indonesian Vegetables Research Institute, Assessment Institute for Agricultural Technology East Java and Bali, Agricultural Extension Service of East Java and Bali, Udayana University and FIELD Foundation Indonesia. Any errors and shortcomings in analysis and interpretation of results are the responsibility of the author.

\section{References}

Adanacioglu, H. (2017). Factors affecting farmers' decisions to participate in direct marketing: a case study of cherry growers in the Kemalpasa District of Izmir, Turkey. Renewable Agriculture and Food Systems, 
Jurnal Ekonomi Pembangunan: Kajian Masalah Ekonomi dan Pembangunan, 20 (2), 2019, 163-175

32(4), 291-305. https://doi.org/DOI: $10.1017 / \mathrm{S} 1742170516000193$

Ali, M. (2016). A synthesis. In Chili (Capsicum spp.) Food Chain Analysis: Setting Research Priorities in Asia (pp. 1-20).

Bowman, M. S., \& Zilberman, D. (2013). Economic factors affecting diversified farming systems. Ecology and Society, 18(1). https:// doi.org/10.5751/ES-05574-180133

BPS. (2011). Monthly Data Report of Social and Economic. Jakarta: Indonesian Statistical Agency.

BPS. (2015). Statistik Tanaman Sayuran dan Buah Semusim Indonesia 2014. Jakarta: Badan Pusat Statistik.

Chagomoka, T., Afari-Sefa, V., \& Pitoro, R. (2014). Value chain analysis of traditional vegetables from Malawi and Mozambique. International Food and Agribusiness Management Review, 7(4), 59-86.

de Janvry, A., \& Sadoulet, E. (2002). World poverty and the role of agricultural technology: direct and indirect effects. Journal of Development Studies, 38(4), 1-26.

Dey, D. (2001). Commercial greenhouse vegetable production. In Agri-Fact (No. 250/830-2). Alberta.

Dong, H., Campbell, B., \& Rabinowitz, A. N. (2019). Factors impacting producer marketing through community supported agriculture. PLOS ONE, 14(7), e0219498. Retrieved from https://doi.org/10.1371/ journal.pone.0219498

Durán, C. A., \& Wives, D. G. (2018). Decision making and agriculture: a recent review of organic farming. Desenvolvimento Em Questão, 16(43), 2237-6453.

Feder, G., \& Savastano, S. (2017). Modern agricultural technology adoption in subSaharan Africa: Four country analysis. In P. Pingali \& G. Feder (Eds.), Agriculture and Rural Development in a Globalizing World: Challenges and Opportunities (pp. 11-25). Oxon and New York: Eartscan from Routlegde.

Freedman, D. (2009). Statistical Models: Theory and Practice, Revised Edition. Cambridge: University Press,.

Huang, J., Hu, R., van Meijl, H., \& van Tongeren, F. (2004). Biotechnology boosts to crop productivity in China: trade and welfare implications. Journal of Development Economics, 75(1), 27-54. https://doi.org/https://doi.org/10.1016/j. jdeveco.2003.07.005

Ikerd, J. (2011). Essential principles of sustainable food value chains. Journal of Agriculture, Food Systems, and Community Development, 1(4), 15-17.

Johnson, G., Weinberger, K., \& Wu, M. E. (2008). The Vegetable Industry in Tropical Asia: An overview of production and trade with a focus on Thailand, Indonesia, the Philippines, Vietnam, and India,. Taiwan.

Juniman, J. (2013, June). Yearly inflation increase, but the BI rate remains on hold. BII Economic Research.

Keatinge, J. D. H., Yang, R.-Y., Hughes, J. d'A., Easdown, W. J., \& Holmer, R. (2011). The importance of vegetables in ensuring both food and nutritional security in attainment of the Millennium Development Goals. Food Security, 4(3), 491-501.

Kumar, G. B. (2009). Factors affecting farmers' decision to cultivate high-valued crops: a case study of Burdwan District of West Bengal. IASSI Quarterly, 28(1), 148-159.

Leavy, J., \& Poulton, C. (2007). Commercialisations in smallholder agriculture: a general framework. 5th International Conference on the Ethiopian Economy. Addis Ababa: Ethiopian Economic Association (EEA). 
Luther, G. C., Mariyono, J., Purnagunawan, R. M., Satriatna, B., \& Siyaranamual, M. (2018). Impacts of farmer field schools on productivity of vegetable farming in Indonesia. Natural Resources Forum, 42(2), 71-82. https://doi.org/10.1111/14778947.12144

Mariyono, J., Gunistiyo, Waskito, J., Sumarno, Nurwildani, M. F., \& Kuntariningsih, A. (2019). Role of microcredit and technology adoption in sustaining farmers' welfare. Journal of Rural Development, 38(1), 102122.

Mariyono, J., Kuntariningsih, A., Dewi, H. A., Latifah, E., Daroini, P. B., Negoro, A. A., ... Luther, G. (2017). Pathway analysis of vegetable farming commercialization. Economic Journal of Emerging Markets, 9(2), 115-124. https://doi.org/10.20885/ ejem.vol9.iss2.art1

Mulu-Mutuku, M. W., Odero-Wanga, D. A., Ali-Olubandwa, A. M., Maling'a, J., \& Nyakeyo, A. (2013). Commercialisation of traditional crops: are cassava production and utilisation promotion efforts bearing fruit in Kenya? Journal of Sustainable Development, 6(7), 48-58.

Nandi, R., Gowdru, N. V., \& Bokelmann, W. (2017). Factors influencing smallholder farmers in supplying organic fruits and vegetables to supermarket supply chains in Karnataka, India: a transaction cost approach. International Journal of Rural Management, 13(1), 85-107. https://doi. org/10.1177/0973005216689319

Noorhadi, N., \& Sudadi, S. (2003). Kajian pemberian air dan mulsa terhadap iklim mikro pada tanaman cabai di tanah entisol. Jurnal Ilmu Tanah Dan Lingkungan, 4(1), 41-49.

O'Loughlin, T. (2011, January 8). Red hot chilli prices bring a tear to the eye. Sydney Herald Morning.
Odiaka, O. E., Osupala, A., \& Odiaka, N. I. (2013). Factors influencing the adoption of technologies on vegetable crops by small scale farmers in Makurdi local government area of Menue state, Nigeria. Acta Horticulturae, (1007), 657-664. https://doi. org/10.17660/ActaHortic.2013.1007.76

Pingali, P. L., \& Rosegrant, M. W. (1995). Agricultural commercialization and diversification: processes and policies. Food Policy, 20(3), 171-185.

Poole, N. D., Chitundu, M., \& Msoni, R. (2013). Commercialisation: a meta-approach for agricultural development among smallholder farmers in Africa? Food Policy, 41, 155-165.

Purwantini, T. B., Saptana, S., \& Suharyono, S. (2012). Program kawasan rumah pangan lestari (KRPL) di Kabupaten Pacitan: analisis dampak dan antisipasi ke depan. Analisis Kebijakan Pertanian, 10(3), 239256.

Selvaraj, K. N. (2009). Impact of improved vegetable farming technology on farmers' livelihoods in India. Acta Horticulturae, 809, 121-126.

Sriwichailamphan, T., \& Sucharidtham, T. (2014). Factors Affecting Adoption of Vegetable Growing Using Organic System:A Case Study of Royal Project Foundation, Thailand. International Journal of Economics \& Management Sciences, Vol. 3, pp. 1-7. https://doi.org/10.4172/21626359.1000179

Turvey, C. G. (2017). Historical developments in agricultural finance and the genesis of America's farm credit system. Agricultural Finance Review, 77(1), 4-21.

Weinberger, K., \& Lumpkin, T. A. (2007). Diversification into horticulture and poverty reduction: a research agenda. World Development, 35(8), 1464-1480. 
Wicaksena, B., \& Permani, R. (2011, October). Indonesian chilli farmers' participation at the supermarket channel. GoLive Indonesia.

Woolverton, A., Okello, J., Binci, M., \& Neven, D. (2014). Attitudes and decision-making in smallholder commercialization. In Andrea Woolverton \& D. Neven (Eds.), Understanding Smallholder Farmer Attitudes to Commercialization: The Case of Maize in Kenya (pp. 16-34). Rome: Food and Agriculture Organization of The United Nations. 